\title{
Citizen Contention and Campus Calm: The Paradox of Chinese Civil Society
}

\section{Citation}

Perry, Elizabeth J. 2014. "Citizen Contention and Campus Calm: The Paradox of Chinese Civil Society." Current History 113, no. 764: 211.

\section{Published Version}

http://www.currenthistory.com/Article.php?ID=1162

\section{Permanent link}

http://nrs.harvard.edu/urn-3:HUL.InstRepos:12841977

\section{Terms of Use}

This article was downloaded from Harvard University's DASH repository, and is made available under the terms and conditions applicable to Open Access Policy Articles, as set forth at http:// nrs.harvard.edu/urn-3:HUL.InstRepos:dash.current.terms-of-use\#OAP

\section{Share Your Story}

The Harvard community has made this article openly available.

Please share how this access benefits you. Submit a story.

\section{Accessibility}




\title{
Citizen Contention and Campus Calm: \\ The Paradox of Civil Society in Post-Tiananmen China
}

\author{
Elizabeth J. Perry \\ Harvard University
}

Civil society in contemporary China presents a perplexing paradox. Despite the brutal suppression of the 1989 Tiananmen Uprising, social contention and associational activism swelled over the ensuing years. One might have expected the ruthless June Fourth repression of the massive student movement to have deterred subsequent contestation, but in fact the frequency of protest has steadily escalated in the past twenty-five years. Moreover, China today is host to countless grassroots (as well as government-sponsored) NGOs, foundations, and charities - not to mention a vibrant sphere of online public debate; in contrast to 1989, a nascent civil society can now be said to exist. Nowhere is this organization and societal engagement more evident than among college students. There are, however, few signs of another student-led "democracy movement" looming on the horizon. Instead, university campuses in the People's Republic of China these days form a critical component of an apparently effective web of support and stability for the extant political system.

The scope and spread of protest in post-1989 China has been impressive. The early 1990s witnessed a wave of violent tax riots by farmers complaining of "unfair burdens." When the central government responded to the rural unrest with an historic decision to abolish China's centuries-old agricultural tax, the locus of protest shifted from the countryside back to the cities. In the late 1990s the privatization and bankruptcy of many state enterprises prompted laid-off and retired workers to lodge petitions and stage sit-ins at factories and government offices in opposition to plant closures and paltry pensions. In the 2000s, as the negative sideeffects of rapid economic reform became increasingly visible, environmental pollution sparked "not-in-my-backyard" rallies among a growing middle class anxious to protect its newly acquired property and its health. State-sanctioned infrastructure development and commercial real estate projects ignited angry remonstrations by displaced residents. Labor disputes erupted with claims to higher wages and better working conditions. Migrant workers demanded that their children be permitted to sit for university entrance examinations in the cities where their parents labored. And yet, amidst this explosion of protest activity by 
seemingly all manner of aggrieved citizens, China's university campuses have remained remarkably quiet.

\section{THREAT AVERTED}

Averting campus unrest in China is no mean feat. Over the course of the twentieth century, every generation of Chinese university students played a catalytic role in a cycle of protest movements that transformed the political trajectory of the country. The Chinese Communist Party (CCP) traces its own origins to the May Fourth Movement of 1919, when nationalistic students streamed out of college campuses onto the streets to denounce Japan's threat to Chinese sovereignty. Two years later, a small band of intellectuals - led by the Dean and Librarian of Peking University - founded the CCP to spearhead a revolution intended to restore China's national pride. In the 1930s and 1940s, thousands of college students suspended their studies to participate in the Communist revolution and its front organizations - first in the war against Japan (1937-45) and then in the Civil War against the Nationalist Party (1945-49). Just a few years after the establishment of the People's Republic of China (PRC) in 1949, students rallied to Chairman Mao's injunction to "let a hundred flowers bloom" by offering spirited criticisms of the new socialist system; shocked by the depth of dissent, the PRC leadership unleashed a draconian "Anti-rightist Campaign" in the summer of 1957. A decade later, campus protest again augured radical change when Chairman Mao called upon student Red Guards to jumpstart his Great Proletarian Cultural Revolution. In 1966, Beijing's leading universities served as launching pads for Mao's final revolutionary quest. For the better part of the Cultural Revolution decade (1966-76), mass criticism and "class struggle" supplanted classroom instruction as the main campus activity. When the Tiananmen Uprising erupted only thirteen years after the conclusion of the Cultural Revolution, it looked as though China's university students were once again poised to spark a major political transformation. The bloody suppression of June Fourth not only stymied the call for fundamental political reform on the part of millions of protesters; it also stemmed the generational tide of politically influential student protest that had punctuated China's entire twentieth century. For the past twenty-five years now, Chinese campuses have remained uncharacteristically tranquil. The anomaly appears even starker in light of the cascade of momentous events, invigorated if not always instigated by restive students, which occurred elsewhere in the world during this same period: Eastern Europe's Revolutions of 1989, the fall of the Soviet Union, the Color Revolutions, and Arab Spring for example.

In the immediate aftermath of June Fourth, journalistic and scholarly consensus in the West ascribed the disappointing failure of China's 1989 Tiananmen Uprising - in contrast to the stunning success of anti-Communist movements across Eastern Europe later that year - to the relative weakness of Chinese civil society. On the one hand, Poland's Solidary, Czechoslovakia's Charter 77, and Hungary's Danube Circle were applauded as part of an emerging urban civil 
society whose rise had spelled the demise of Communist regimes from Bucharest to Budapest. On the other hand, the absence of a comparable level of autonomous associational activity in Beijing was blamed for the durability of the PRC's authoritarian political system.

It is certainly true that the Tiananmen Uprising occurred in the absence of a robust and independent urban civil society of the type that is often presumed to be a prerequisite for democratization. Although so-called "democracy salons" had sprouted up on a number of Chinese university campuses in the 1980s, these were small and nebulous entities, closely monitored by the state's security apparatus. The millions of protesters who marched in Beijing and other major Chinese cities in the spring of 1989 were for the most part mobilized not by new civil society associations, but instead via pre-existing socialist institutions: public universities, state-owned enterprises, official mass associations, and even government and party agencies. When central leaders finally issued an unambiguous directive to demobilize the movement, these organizations quickly fell into line and the protest crumbled almost overnight.

Tracing the failure of Tiananmen to the weakness of Chinese civil society heightens the paradox of post-1989 developments, however. For the past quarter century has not only seen a torrent of popular protest in virtually all corners of Chinese society outside of academia; recent years have also witnessed an unprecedented growth in volunteerism and NGO activism - or a fledgling "civil society" - that is particularly pronounced on college campuses. Students and professors are at the forefront of an extraordinary surge in associational participation and community service. Yet, further deepening the paradox of post-' 49 trends, applications to join the Chinese Communist Party are also at an all-time high among university students and instructors. Contrary to conventional predictions, the growth of protest and civil society in contemporary China seems more conducive to authoritarianism resilience than to imminent democratization.

At the center of the PRC's anomalous situation is the compliance of its academics. The causes of this complicity are multiple. First, and most obvious, is the array of control mechanisms that the party-state deploys to maintain order on university campuses. Second is a range of more subtle techniques of cultural governance designed to produce political allegiance and regime loyalty among citizens in general and students in particular. Third, and arguably most important, are the various opportunities for regime-supportive civic engagement and service afforded by the recent expansion of civil society. Ironically, the increased associational activity to be found among Chinese students today is working to underpin, rather than to undermine, the authority of the Communist party-state. This irony is underscored by the fact that the very term "civil society" (gongmin shehui) is one of seven topics (along with universal values, freedom of speech, civil rights, crony capitalism, judicial independence, and historical errors of 
the Chinese Communist Party) that the current regime has officially banned from public discourse on grounds that the concept reflects "dangerous Western influences."

\section{CAMPUS CONTROLS}

Let us consider first the control mechanisms. Acutely aware of the potential threat of campus turmoil, China's Communist party-state has developed a battery of methods to monitor and restrain student behavior. College students are organized by "homeroom" (banji) as well as by class year (nianji), with these units headed by politically reliable peers who convey information both from and to the university administration. Peer surveillance and pressure is embedded within a professional oversight hierarchy. The mainstay of the control regimen is made up of so-called "guidance counselors" (fudaoyuan), trained personnel tasked with keeping close tabs on their student charges to ensure that their beliefs and behavior do not violate approved boundaries. Although a system of guidance counselors was originally introduced at Tsinghua University as early as 1953, it assumed renewed and enlarged significance after 1989. Some of the counselors' duties are similar to those of resident tutors on many Western college campuses: helping to resolve personal problems, offering academic advice, and generally serving as older role models for puerile undergraduates. Unlike resident tutors at Oxford or Harvard, however, the chief responsibility of the fudaoyuan is ideological and political. Typically young instructors in their late twenties or early thirties, the guidance counselors (assisted by student informants) report directly to the deputy party secretaries responsible for student work at all levels of the university structure.

In recent years these control methods have been "modernized" with the aid of new techniques and technologies. For example, as in the United States, mental health facilities are now a staple feature of Chinese college campuses. But in the PRC the definition of "mental illness" is broadly construed to include ideas and inclinations that the state deems politically dangerous, and the results of mandatory mental health screening for freshmen are forwarded to political cadres for analysis and possible preventative or punitive action. Another "modernized" means of gauging (and guiding) student opinion is afforded by the spread of the internet and social media. In 2008 China passed the U.S. as the world's biggest internet user, with micro-blogging via Weibo (the Chinese equivalent of Twitter) and messaging via WeChat (an alternative to Facebook) especially popular among college students. Blog postings, text messages, and other cellular and electronic communications facilitate the growth of (both virtual and actual) civil society among Chinese university students. They also enable the state to better monitor this burgeoning activism. Counselors and cadres combat subversive or suspicious content not only through censorship, but also by commissioning counter-posts that promote the officially prescribed point of view. 
The party-state deploys proactive as well as reactive measures in the effort to channel student sentiment in directions favorable to the CCP's agenda. Since the 1990s, ideological and political education (sixiang zhengzhi jiaoyu) and military training (junxun) have been standard components of the university curriculum. Such classes and exercises are designed to inculcate regime-supportive dispositions and deportment. Of growing importance in recent years has been instruction in "cultural proficiency" (wenhua suzhi) and "national character" (guoqing), which presents Chinese history, art, philosophy and literature in ways that postulate an organic connection and essential compatibility between the splendors of China's ancient "tradition" and its contemporary "socialist" system. This is an extension of the Patriotic Education Campaign, launched in the aftermath of the Tiananmen Uprising, which highlighted both China's national cultural heritage and its modern revolutionary experience as twin sources of legitimacy for the Chinese Communist Party. Cultural proficiency - thanks to generous funding from the Central Propaganda Department - is promoted not only in the classroom, but also in theaters, museums, field trips to ancient and revolutionary historical sites, invited lectures by distinguished scholars and public intellectuals, research projects by renowned teams of social scientists and humanists, and so forth. The universities constitute a key node in a massive party-state initiative in cultural governance intended to convince citizens that CCP rule is endowed with "Chinese characteristics" which render its authority both natural and necessary.

While overt control mechanisms and formal ideological instruction are a common cause for complaint among Chinese university students, the more subtle and sophisticated modes of cultural governance appear to enjoy considerable success. To be sure, one hears many criticisms of the contemporary political system on Chinese campuses; seldom, however, is there a suggestion on the part of these critics that the system is in any way "un-Chinese." Under the banner of patriotism, the Propaganda Department's hybrid of China's ancient heritage with its $20^{\text {th }}$ century revolutionary legacy to fashion an allegedly seamless "socialism with Chinese characteristics" (as Deng Xiaoping dubbed the post-Mao system) seems to have taken firm root. For a political system whose basic ideology and institutions were imported almost wholesale from the Soviet Union, achieving this level of cultural recognition and acceptance (at least among those who identify as Han Chinese, if not among ethnic minorities such as Tibetans or Uighurs) is a significant achievement.

\section{STUDENT VOLUNTEERS}

Even more effective in eliciting campus compliance than either control mechanisms or cultural governance, I would submit, are the expanded opportunities for voluntarism and community service that have developed apace in recent years - especially since the Wenchuan Earthquake and the Beijing Olympics of 2008. Student clubs of various sorts had been a feature of Chinese college life since the 1980s. The past few years, however, have seen a mushrooming of organizations whose mission extends beyond conventional campus recreational and 
educational activities to the provision of social services outside the academy. Although the Xi Jinping administration has blacklisted "civil society" as a dangerous Western notion, its emergence is actually an important contribution to campus calm in the contemporary PRC. The space for meaningful participation afforded by the growth of grassroots NGOs encourages college students (and their professors) to concentrate on varieties of activism that directly and indirectly benefit Communist rule - relieving the state of a portion of its social welfare burden while at the same time channeling youthful energy away from potentially disruptive behavior. Many of the associations that have sprung up in recent years enjoy close connections to the party-state and its official "mass associations." The Chinese Communist Youth League (CYL) plays a particularly prominent role on Chinese university campuses, not only as a training camp for prospective party members but also as sponsor for a range of volunteer and philanthropic activities. The best known of these CYL endeavors, Project Hope, mobilizes a steady stream of college student volunteers to help staff the thousands of elementary schools that it has recently constructed in impoverished areas of the country.

While a disproportionate share of financial and political resources is concentrated in such GONGOs, or government-organized non-governmental organizations, they by no means monopolize the field of associational activity either on or off campus. The Chinese Academy of Social Sciences, a government think tank, reported an official figure of over 800,000 "social organizations" and "social associations" in 2013. Unofficial estimates, which include a multitude of unregistered groups, put the total number of grassroots NGOs of various sorts at several million. Thanks to recent reforms making it easier for social service organizations to register with local municipal bureaus of civil affairs, grassroots groups have been able to enlarge their fundraising efforts of late. Since the catastrophic 2008 Wenchuan Earthquake, when both government and social media encouraged citizens to dig deep into their own pockets to aid the disaster victims, the practice of private giving has spread rapidly in Chinese society. Charitable foundations and philanthropic venture funds have proliferated, now numbering in the thousands, and affording ever expanding opportunities for community activism. The Wenchuan quake not only encouraged the rise of private philanthropy; it also triggered a massive volunteer movement when concerned citizens from across the country, especially college students, flocked to Sichuan to offer their personal assistance to the rescue effort. The trend of youthful voluntarism for public causes accelerated a few months later when the government (via the CYL, the Confucius Institute and other official agencies) mobilized large numbers of student volunteers to help out at the Beijing Olympics. The experiences of $\mathbf{2 0 0 8}$ were clearly transformative for the current generation of young Chinese, some of whom went on to establish private charities of their own and many others of whom have continued the practice of devoting a generous amount of personal time and money to further their favorite causes. 
While battling HIV/AIDS and environmental pollution animated the first generation of China's grassroots NGO activists, today both the issues and the motives that underlie them are remarkably wide ranging. A variety of religious faiths - from Christianity to Buddhism - is inspiring the establishment of privately operated medical clinics and nursing homes, for example. A secular sense of social responsibility is fueling donation drives for everything from books for school libraries to winter coats for the poor. And the influence of socialist ideals can be detected in the rapid growth of labor NGOs that provide legal and welfare services for downtrodden workers.

\section{A WORRIED STATE}

Under some pressure to live up to its own officially espoused socialist ideology by upgrading the provision of social services, the party-state is anxious to reap the positive dividends of this fluorescence of community activism. In some cases, local governments even contract with civic organizations to facilitate the implementation of mandated welfare policies and other social services. But the state's top priority remains that of "stability maintenance" (weiwen), or the perpetuation of Communist party rule. Fearful that networks of social activists could pose an existential threat similar to what transpired in Eastern Europe in 1989, the government keeps close tabs on NGOs and makes it difficult (through registration rules as well as public security surveillance and harassment) for local groups to forge links with counterparts in other parts of the country. The party-state pays special attention to constraining the involvement of intellectuals - college students included - in order to prevent their serving as bridges between groups operating in different locations or composed of disparate social classes or interests. An outside observer might suspect PRC authorities of betraying a streak of paranoia in devoting so much concern to combating the supposed political threat of its university students. After all, rapid expansion in higher education enrollments, combined with the growth of professional and technical training at the expense of liberal arts education, has rendered college students in China today - as in many other countries - more focused on securing a job than on sabotaging the system. But in fact the party-state's worries are hardly groundless. In addition to the historic cycles of Chinese student protest, there is ample contemporary evidence of the challenge posed by student power in those parts of Greater China where campus controls are less stringent than on the mainland.

As the PRC keenly appreciates, the possibility of college students acting as sparkplugs of political protest certainly did not disappear on June Fourth 1989. Twenty-five years after the suppression of the Tiananmen Uprising, events in both Taiwan and Hong Kong demonstrate the continuing capacity of Chinese students - in concert with civil society allies - to trigger mass movements with unwelcome political implications for Beijing. In Taiwan, the Sunflower Student Movement (taiyanghua xueyun) occupied the Legislative Yuan for the first time in its history and forced the ruling party to reconsider a cross-strait service trade agreement with the 
PRC. In Hong Kong, students spearheaded some of the largest demonstrations in the history of the island to register dissatisfaction with the PRC's stipulated process for nominating the city's chief executive.

It is too soon to assess the long-term impact of either of these two protest movements, but the events in Taiwan and Hong Kong this spring and summer have surely reinforced PRC authorities' worries about the dangers of an alliance between politicized student activists and an awakened civil society. Instead of resorting to crackdowns by riot police, as occurred in both Taipei and Hong Kong, Beijing would obviously far prefer to prevent the emergence of student-inspired protest in the first place. Ensuring that college campuses are tightly monitored and that student energies are channeled into system-supportive rather than system-subversive modes of activism is therefore a critical element in the regime's comprehensive scheme for "stability maintenance."

\section{THE UPPER HAND}

Like so many features of the contemporary Chinese scene, the role of civil society would seem to challenge conventional wisdom concerning the relationship between socioeconomic development and political change. Counter-intuitively, the recent increase of popular protest and associational activity in the PRC has proven to be more of a help than a hindrance to the perpetuation of Communist party-state rule. Rather than providing a platform for political agitation and democratization, burgeoning civil society in mainland China has offered an outlet for public service that relieves the state of some of its own onerous welfare burden while also fulfilling citizens' growing desire for social engagement.

The pervasive contestation that takes place outside the gates of university campuses, while sometimes sparked by grassroots NGOs, has concentrated on economic and environmental issues that do not directly challenge CCP authority. And the campuses themselves, the cradle of political ferment in $20^{\text {th }}$ century China, have remained uncharacteristically quiet for the past twenty-five years.

To be sure, the PRC is not the only case where a rising civil society did not produce democratization. Inter-war Germany and Japan present examples of another, more disturbing, scenario in which the development of vociferous protest and vibrant associations in the 1920s and ' 30 s presaged a turn toward right-wing militarism. Both Weimar Germany and Taisho Japan lacked the robust political institutions necessary to channel the activism of an aroused citizenry in ways productive of political liberalism. The result in those cases was not democracy, but fascism and the scourge of World War II. 
In stark contrast to inter-war Germany and Japan, however, the PRC today does not lack for strong political institutions. The Chinese Communist Party retains a tight grip on both government and society. Thus, while a turn toward aggressive militarism is not beyond the realm of possibility, a more likely trajectory for the PRC is that of continued Communist Party rule. To date, the party-state has shown a deft ability to keep the upper hand amidst an extraordinary explosion of citizen contention.

A key pillar of this successful strategy has been the prevention of campus unrest. Thanks in no small part to new opportunities for volunteerism afforded by the dramatic development of civil society, China's university students are at present devoting more energy to community service than to political mobilization. Hostile as the top leadership is toward the whole idea of civil society, the Communist party-state's survival has actually been prolonged by its emergence.

Still one cannot help but wonder: If China's authoritarian polity is so resilient, why are its leaders so anxious about the system's durability? Why do they feel compelled to lavish such extravagant resources on the quest for "stability maintenance?" Judging by recent events in Taipei and Hong Kong, the specter of an independent Chinese civil society - aroused by impassioned university students - could indeed at some future point pose a serious threat to the endurance of the Communist party-state. 